\title{
Invited Paper Stubble height as a tool for management of riparian areas
}

\author{
WARREN P. CLARY AND WAYNE C. LEININGER
}

Authors are project leader, Forestry Sciences Laboratory, Rocky Mountain Research Station, USDA Forest Service, 316 E. Myrtle St., Boise, Ida. 83702 , and professor, Department of Rangeland Ecosystem Science, Colorado State University, Fort Collins, Colo. 80523.

\section{Abstract}

Stubble height, a measure of the herbaceous vegetation remaining after grazing, has been widely used in recent years to gage the impacts of grazing use in riparian areas. Stubble height is a short-term management guide that should only be applied to help attain long-term ecological objectives; it should not be thought of as a long-term management objective.

Maintaining a minimum stubble height helps preserve forage plant vigor, retain sufficient forage to reduce cattle browsing of willows (Salix spp.), stabilize sediments, indirectly limit streambank trampling, maintain cattle gains, and provide an easily communicated management criterion. Based on limited specific research of riparian system response and on knowledge of the characteristics of how cattle graze, a $10-\mathrm{cm}$ residual stubble height is recommended by the authors as a starting point for improved riparian grazing management. Monitoring should then be conducted to determine if an adjustment is needed. In some situations, $7 \mathrm{~cm}$ or even less stubble height may provide for adequate riparian ecosystem function, particularly when streambanks are dry and stable or possibly at high elevations where vegetation is naturally of low stature. In other situations, 15-20 $\mathrm{cm}$ of stubble height may be required to reduce browsing of willows or limit trampling impact to vulnerable streambanks. The recommended criterion would apply to streamside and nearby meadow sites with hydrophilic or potentially hydrophilic vegetation, but not directly to dry meadows or even to all wet meadows. Stubble height may have little application where the streambanks are stabilized by coarse substrates, or the channels are deeply incised.

The effects of residual stubble height in riparian functions have received limited direct experimental examination. Consequently, much of the information in this review was derived from studies indirectly related to the questions raised and, to some extent, from observations of experienced professionals. The authors have identified areas of scientific investigation needed to improve our understanding of the effects of stubble height on riparian function and grazing management.

Key Words: Grazing, livestock management, streambanks, trampling, utilization, willow

In the early settlement history of the western United States management of riparian grazing lands was pretty straightforward-no irrigation or stock water to worry about-just turn the

Authors express their appreciation to William C. Krueger, Quentin D. Skinner, M.J. Trlica, and 2 anonymous reviewers for their thoughtful and helpful comments on an earlier draft of the manuscript.

Manuscript accepted 22 May 2000.

\section{Resumen}

La altura del rastrojo, una medida de la vegetación herb·cea remanente después de que ha sido sujeta apacentamiento, ha sido ampliamente utilizada en años recientes para medir el impacto del apacentamiento en las áeas ribereñas. La altura del rastrojo es una guáa de manejo a corto plazo que debe ser aplicada solo para ayudar a lograr los objetivos ecológicos de largo plazo y no debe ser tomada como un objetivo de manejo a largo plazo.

El mantener una altura mánima del rastrojo ayuda a preservar el vigor de las plantas forrajeras, retener suficiente forraje para reducir el ramoneo de "Willows" (Salix spp.) por el ganado, estabilizar los sedimientos e indirectamente limitar el pisoteo del banco de la corriente, mantener las ganancias del ganado y proveer un criterio de manejo f-cilmente comunicable. Basado en la escaza investigación especifica sobre la respuesta de los sistemas ribereños y en el conocimiento de como el ganado apacienta, se recomienda una altura del rastrojo de $10 \mathrm{~cm}$ como el punto inicial para el manejo del apacentamiento que mejore las áeas ribereña. EI monitoreo debe entonces ser conducido para determinar si es necesario un ajuste. En algunas situaciones 7 o menos centámetros de altura del rastrojo pueden ser suficientes para el buen funcionamiento del sistema ribereño, particularmente cuando el banco de la corriente est'n secos y estables o posiblemente en elevaciones altas donde la vegetación por naturaleza es de porte bajo. En otra situaciones 15 a $20 \mathrm{~cm}$ pueden ser requeridos para reducir el ramoneo de "Willows" o limitar el impacto del pisoteo en los bancos de corriente vulnerables. El criterio recomendado aplicaráa a las playas y vegas cercanas con vegetación hidrofálica o potencialmente hidrofálica, pero no directamente a las vegas secas o no a todas las vegas $h$ medas. La altura del rastrojo puede tener poco aplicación donde el banco de la corriente esta estabilizado por estratos gruesos o los canales de incisión profunda.

Los efectos de la altura del rastrojo residual en las funciones ribereñas ha recibido poca atención experimental directa.. Consecuentemente, mucha información de esta revisión se derivó de estudio relacionados indirectamente a las preguntas surgidas y en parte también de observaciones de profesionales experimentados. Los autores han identificado áeas de investigación cientáfica necesarias para mejorar nuestro entendimiento de los efectos de la altura del rastrojo en las funciones de ribereñas y manejo del apacentamiento.

livestock out in the spring and take them home in the fall. We now know that proper management of these highly diverse ecosystems is not that easy. These land-water ecotones are among the most ecologically productive and diverse of all terrestrial habitats, and the influence of moving water within stream ripari- 
an zones often results in rapid and dynamic habitat changes (Naiman et al. 1993).

As society's interest in public land has increased, interest in riparian grazing management issues has increased as well (US GAO 1988, Belsky et al. 1999). Many managers are currently using residual herbaceous stubble height in the riparian zone as a measure of the vegetation remaining after grazing. Stubble height has also been suggested as a gage to various impacts of grazing use (Skinner 1998). In this paper we present what is known about stubble height and its use as a tool for managing riparian areas.

\section{Historical Perspective}

Stubble height standards were used earlier in this century to guide the grazing management of rangelands, particularly those in the Southwest (Crafts 1937, Parker 1942). Several range scientists developed techniques for determining stubble height (Reid and Pickford 1941, Canfield 1942a, 1942b, 1944). Guidelines were specific to each forage species and generally crafted to approximate a utilization level determined at the end of the grazing season or year. In some instances, stubble height standards were presented for different seasons of the year (Crafts 1937).

Textbooks continued to present stubble height and height-weight relationships as part of vegetation measurements through the 1980s (Brown 1954, Cook and Stubbendieck 1986, Bonham 1989), often as a method to estimate utilization (Stoddart et al. 1975, Holechek et al. 1989). However, field use of stubble height seemed to give way to direct estimates of utilization percentages (Sanders 1998). Use of utilization per se as a management tool has been questioned (Frost et al. 1994, Sharp et al. 1994, and by several participants at a workshop [OSU, AES 1998]). A broad contention was that utilization measures are flawed because of irregular consumption within and between plants, mismatching of utilization standards and plant phenology, problems in determination of actual utilization levels, and confusion of management tools with management objectives (OSU-AES 1998). Similar issues can be raised for the use of stubble height as a grazing management tool.

Various researchers have focused on residual vegetation as the important element in grazing management. A number of residual vegetation recommendations have been developed through research and experience. For example, herbage production was maintained and maximum financial returns from livestock grazing were achieved when approximately $340 \mathrm{~kg} \mathrm{ha}^{-1}$ of residue was preserved on shortgrass prairie in eastern Colorado (Bement 1969). In California the residue needed to maintain an adequate mulch layer and soil organic matter to support mountain meadow stability varied from 110 to $3,200 \mathrm{~kg}$ $\mathrm{ha}^{-1}$ depending upon meadow condition and elevation (Ratliff et al. 1987). Maintenance of minimum residue amounts has been recommended to maintain herbivore productivity (Heady and Child 1994). Approximate residual biomass can be estimated from height-weight relationships and stubble heights (Ratliff et al. 1987, Mitchell et al. 1993, Heady and Child 1994, Leonard et al. 1997).

Some people have stated that stubble height may possibly be easier to visualize, measure, and communicate than is residual weight of forage or estimates of percentage utilization (Canfield 1942a, USDI-BLM 1996, Leonard et al. 1997). Others have objected to the general application of stubble height or other utilization standards as not appropriate for all situations (Chaney et al. 1993, George 1996).

A determination of current livestock use does appear to be important for most management situations. Holechek et al. (1998, 1999), after reviewing numerous grazing studies, concluded that stocking rate rather than the grazing system was the primary factor that affected range condition and financial returns. Forage utilization (expression of forage removed) and residual vegetation (expression of forage remaining) both provide some measure of comparative stocking rates.

\section{How Are Riparian Areas Different From Adjacent Uplands?}

Riparian ecosystems occur along the edges of water bodies, but are usually associated with streams. Although vegetation is often the most conspicuous part of a riparian ecosystem, the entire system comprises a variety of life forms and abiotic environmental features (Kauffman and Krueger 1984). Unbound water either directly or indirectly influences all of the functional and structural characteristics of these zones (Hawkins 1994). Riparian ecosystems are of great interest because, although ecologically connected, they are usually functionally and structurally unique from adjacent upland systems. Near-stream environments are hydrologi- cally and geomorphically dynamic in that periodic flooding typically scours channel and flood plain surfaces in some areas and deposits material in others. These natural disturbances form the complex habitats found in riparian systems (Hawkins 1994, Swanson 1994). Unfortunately, the disturbance and successional patterns of riparian areas are highly vulnerable to influence by human activities that are often concentrated in water-influenced areas (Groeneveld and Or 1994, Busch and Scott 1995). Such activities include grazing, recreation, logging, mining, water diversion, agriculture, and road construction.

A major function of riparian-stream systems is to provide routing or transfer of water, energy, sediment, nutrients, particulate organic matter, and organisms (Odum 1978, Gregory et al. 1991, Johnston 1993, Risser 1995). Such transfers are not only in a down stream direction, but may move laterally, sometimes being deposited onto flood plains and at other times moving materials from the land into the stream (Gregory et al. 1991, Kattlemann and Embury 1996). The biogeochemical cycles of riparian areas differ from surrounding uplands or adjacent dry meadows (Green and Kauffman 1989). Wet soil conditions in streamside riparian areas often result in anaerobic situations, at least during the earlier portion of the growing season. Anaerobic biochemical reactions serve to alter the state of elements in water passing through them prior to entering streams and lakes. Under anaerobic conditions, microbial processes help produce reduced forms of elements such as carbon, nitrogen, and sulphur that can be released into the atmosphere (Hussey et al. 1985, Schlesinger 1991, Hill 1996, Schnabel et al. 1996). Riparian areas can serve as a sink for phosphorus-laden sediments, further upgrading water quality (Green and Kauffman 1989, Corley et al. 1999). The presence of herbaceous vegetation improves water quality by enhancing sediment deposition. This process often facilitates the channel restoration process particularly in smallstream (e.g., $\sim 5 \mathrm{~m}$ width or less) systems (Hawkins 1994, Clary et al. 1996, Pearce et al. 1998a).

In most of the western United States, the interface of stream-riparian areas with the more arid uplands creates the ultimate in dynamic ecotones. The upland-riparianaquatic mosaic composes an amazing platform for biotic diversity (Fitch and Adams 1998). The ecotonal nature of riparian areas with their high productivity and variety often supports a highly diverse biota represented by species from adjacent upland and 
aquatic environments, as well as species unique to the riparian area (Odum 1978, Thomas et al. 1979, Kauffman et al. 1985, Larson 1993, Logan 1997).

Cattle congregate on meadows and riparian areas. They favor riparian area forage and water availability, topography, and general lack of physical constraints to grazing as compared to the drier and often rougher characteristics of upland areas (Reid and Pickford 1946, Roath and Krueger 1982b, Pinchak et al. 1991). This leads to particular concern toward grazing impacts (Chaney et al. 1993, Belsky et al. 1999). Because of moving water's erosive energy, maintaining hydrophilic herbaceous and woody plants is extremely important in many riparian situations (Beschta and Platts 1986, Manning et al. 1989, Gregory et al. 1991, Dunaway et al. 1994). If heavily rooted hydrophilic plants such as Nebraska sedge (Carex nebrascen sis Dewey) and Baltic rush (Juncus balti cus Willd.) are replaced by species with less root biomass and root length, streambank instability and channel lateral expansion often occur. This can result in a lowering of the local flood plain water table (Winward 1994). An example of such a species is Kentucky bluegrass ( $\mathrm{Poa}$ pratensis L.), which is widespread on riparian areas where cattle graze heavily and channels are dynamic (Skinner 1998). Its comparatively limited total root lengths provide less streambank protection than species such as Nebraska sedge and beaked sedge (Carex utriculata Booth, formerly C. rostrata Stokes) (Platts and Nelson 1989, Kleinfelder et al. 1992, Hansen et al. 1995). It should be noted, however, many non-meadow stream segments are stabilized by large substrate particles (Rosgen 1996) and are relatively insensitive to the effects of herbaceous composition or livestock use.

A strikingly important function of riparian areas is their contribution to the quality of stream fisheries habitat. Major concerns about the impacts of riparian grazing on fisheries habitats have been raised in recent decades (Armour et al. 1994). Stream channel profile, streambank stability, streamside vegetation, channel bottom embeddedness, stream sediments, and stream temperature are all critical fisheries habitat characteristics that can be directly or indirectly affected by livestock grazing practices (Meehan et al. 1977, Stuber 1985, Bjornn and Reiser 1991, Murphy and Meehan 1991).

Can forage stubble height be of more value as a management tool for riparian areas than on uplands? This may be so, because of the dynamic, multi-dimensional nature of riparian areas. On upland areas forage plant vigor, production, reproduction, and survival, together with soil loss, have been the primary range management concerns (Stoddart et al. 1975, Pieper 1994). Land managers must consider these plus many water-driven factors when managing riparian areas (Winward 1994). Forage stubble height can serve as a surrogate for a variety of management impacts (Skinner 1998). Some of the potential effects of leaving residual stubble height are direct, while others are indirect. Both of these kinds of effects are discussed.

\section{Effects of Using Stubble Height as a Riparian Management Tool}

\section{Direct effects \\ Streambank protection and sediment entrapment}

The ability of vegetation, particularly herbaceous vegetation, to protect stream channels and waterways has been intensively studied since the mid 1900s. Engineers and agronomists worked together to determine the effects of species, stem length, stem density, stem stiffness, and channel characteristics on channel protection and flow resistance (Ree and Palmer 1949, Temple 1982, Masterman and Thorne 1992). In the northeastern United States, streambank vegetation appeared to change the roughness of the channel and shear strength of the substrate and to directly influence the shaping of channel dimensions. The channel form of small streams (peak flow of 0.6 to $2.8 \mathrm{~m}^{3} \mathrm{sec}^{-1}$ ) was found to be greatly influenced by whether the streamside vegetation was trees or herbaceous sod. A narrowing of streams with sodded banks was particularly evident (Zimmerman et al. 1967).

Observations of riparian areas in the western United States have suggested that the type of sod is very important in determining streambank stability. For example, streambanks dominated by Kentucky bluegrass communities appeared to have substantially less stability than those dominated by sedge (Carex spp.) (Platts and Nelson 1989). The root length density of species such as Nebraska sedge may be over 10 times greater and root mass may be over 6 times greater than for a species such as Nevada bluegrass (Poa nevadensis Vasey) (Manning et al. 1989). The benefits of greater root length density and root mass in alluvial meadow streambanks include greater resistance to particle ero- sion and greater resistance to compression and shear (Kleinfelder et al. 1992, Dunaway et al. 1994). Foliage and stem length is also an important factor in protecting streambanks. As streamside vegetation is immersed under rising streamflows and the foliage is laid over from the force of the flow, the longer vegetation length provides the greater protection to the substrate surface (Clary et al. 1996, Skinner 1998).

A key element for restoring degraded stream channels is entrapping and retaining of sediment on or below bank top (Clary et al. 1996). The possibility of forage plant stubble heights directly affecting the potential deposition and retention of sediments was examined in a hydraulics laboratory setting. The amount of sediment entrapped in the channel was a function of the flow and the vegetation blade length. Blades of Kentucky bluegrass of less than $8 \mathrm{~cm}$ appeared to enhance sediment deposition, while $20-\mathrm{cm}$ blades retained a greater percentage of the initial sediment deposits (Abt et al. 1994). Alternatively, the more rigid but less dense vegetation entrapped less sediment (Thornton et al. 1997). Overall, these laboratory studies suggested that short-to-mid length (1-15, or possibly as much as 20 $\mathrm{cm})$ flexible vegetation may be the most effective in supporting the bank building process within a single sedimentation event (Clary et al. 1996, Thornton et al. 1997). Limited experimental data suggest that longer stubble heights (20 to $30 \mathrm{~cm}$ ) will be similarly effective under multiple sedimentation events (Clary et al. 1996). The presence of vegetation with $1.3 \mathrm{~cm}$ of stubble height or greater stabilized 200-700\% more sediment than non-vegetated conditions in laboratory studies (Thornton et al. 1995).

Field tests of the impact of stubble height on sediment deposition and retention, subject to the variability and interactions of the real world, have not shown definitive results. A field test of sediment deposition during winter/spring flow events in 4 natural streams was investigated in Nevada. Four residual vegetation heights $(0,5,10 \mathrm{~cm}$ and unclipped $[\sim 30$ $\mathrm{cm}])$ were tested. There were no differences the first year of the study, but in the second year the 5-cm height often captured significantly more sediment than the other treatments (Bell 1998). Another test of sediment deposition under natural flow was conducted in Wyoming. No significant difference was noted among effects of $0,1,8$, and $15 \mathrm{~cm}$ stubble heights in the first 2 years of relatively low sediment 
deposition (Rumsey 1996 as cited in Skinner 1998). During following years of repeated and strong floods, the 8 and 15 $\mathrm{cm}$ stubble heights appeared to stabilize the greatest amount of sediment (Skinner 1998). Sediment deposition during overland flow was examined in Colorado and Wyoming using a rotating boom rainfall simulator in both the field and in the laboratory. No significant differences were found in runoff characteristics or sediment deposition related to stubble height under conditions of shallow, overland flow (Pearce et al. 1997; 1998a, 1998b; Frasier et al. 1998).

Although sufficient evidence is available to conclude that stubble height has some affect on sediment deposition and retention when the plants are inundated, a complex of factors influence sediment movement and deposition (Pearce et al. 1998b). Skinner (1998) suggested that grazing of vegetation may not be a significant consideration in sediment deposition compared to the effects of channel and streamflow attributes. Several examples of minimum initial vegetation impact are deposits on point bars and on floodplains. On point bars sediments are deposited to a substantial degree by helical flow of the stream meander. This does not require the presence of vegetation, but vegetation will stabilize the deposited material allowing the vertical development of the point bars (Morisawa 1968, Abt et al. 1994). Deposits on floodplains can also occur in the absence of vegetation as the spreading water slows and loses competence (Morisawa 1968). Again, the presence of vegetation is important for long-term stabilization of these deposits.

\section{Forage plant vigor and regrowth}

The effect of defoliation on growth and vigor of forage plants has been a focus of concern throughout the history of range management (Jameson 1963, Bedunah and Sosebee 1995), but little experimental knowledge has been developed on responses of riparian species to defoliation. Most available information is based on observation and professional experience (USDA-FS 1988, Hansen et al. 1995). Generally, it is assumed that riparian forage species can be grazed more intensively than upland species because of higher soil moisture and their surmised regrowth potential (Skinner 1998).

In the Spring Creek study in Wyoming, treatments of weekly to biweekly defoliations to 1,8 , and $15 \mathrm{~cm}$ for 4 years resulted in less biomass for clipped plants as compared with untreated controls,

Table 1. Nebraska sedge stubble heights, Sheep Creek, Colo.

\begin{tabular}{|c|c|c|c|}
\hline & \multicolumn{3}{|c|}{ Percent removal of current standing crop } \\
\hline & $30 \%$ (Light) & $60 \%$ (Medium) & $90 \%$ (Heavy) \\
\hline $\begin{array}{l}\text { Spring } 25 \text { May } \\
\text { Shoot height- } 8 \mathrm{~cm} \\
\text { Stubble height }\end{array}$ & & & \\
\hline $\begin{array}{l}\text { Stubble height } \\
\text { Early summer } 27 \text { Jun } \\
\text { Shoot height- } 20 \mathrm{~cm}\end{array}$ & 3.8 & 2.0 & 0.5 \\
\hline Stubble height & 7.0 & 4.5 & 1.8 \\
\hline $\begin{array}{l}\text { Late summer } \sim 5 \text { Augus } \\
\text { Shoot height }-25 \mathrm{~cm} \\
\text { Stubble height }\end{array}$ & 10.0 & 6.5 & 2.8 \\
\hline $\begin{array}{l}\text { Fall 1 October } \\
\text { Shoot height- } 30 \mathrm{~cm} \\
\text { Stubble height }\end{array}$ & 15.0 & 9.0 & 3.5 \\
\hline
\end{tabular}

although plants clipped at $1 \mathrm{~cm}$ produced more than did plants from the other 2 clipping treatments (Skinner 1998). In a study at Sheep Creek, Colo., Nebraska sedge was subjected to light, medium, and heavy defoliation during either spring, earlysummer, late-summer, or fall for 3 years. Additional treatments included medium defoliation during each of the aforementioned periods (i.e., continuous use treatment) and an untreated control (Table 1). Light and medium defoliations once each year for 3 years appeared to have had little effect on Nebraska sedge leaf lengths, however, heavy defoliation treatments resulted in reductions in leaf growth the following June. Reduction of stubble height to $2.8 \mathrm{~cm}$ in late summer was particularly detrimental to leaf growth (Lamman 1994).

A grazing simulation plot-study conducted in Idaho and Oregon included the components of defoliation, compaction (or trampling), and sometimes, nutrient return. The simulations suggested that creeping bentgrass (Agrostis stolonifera L.) communities would tolerate grazing to a $5-\mathrm{cm}$ level. However, a reduction in the following year's growth was noted in higher elevation sedge-dominated communities when they were grazed to a $5-\mathrm{cm}$ height in the spring, or to a $10-\mathrm{cm}$ height in late summer (Clary 1995).

One reason for differences in the apparent sensitivity of riparian plants to grazing, noted above as compared to defoliation studies cited in the literature, was the consideration of livestock compaction or trampling effects. In the Idaho-Oregon study, the reduction in height growth and biomass production was more consistently related with compaction (or perhaps trampling) than with defoliation (Clary 1995). The simulation of grazing by defoliation alone does not account for physical impacts to plants caused by the grazing animals (Skinner 1998). The compaction or trampling effect on plant growth may often be due to a direct impact on the plants themselves rather than soil compaction as such because bulk densities of riparian soils often recover quickly during the freezethaw cycles of winter (Wheeler 1998, Q.D. Skinner, personal communication).

Managers often depend upon substantial regrowth in riparian plants, such as when grazing is removed at least 1 month before frost (Myers 1989), to attain protective plant cover for the over-winter period. This response, however, is not consistent. For example, lower elevation sites that support disturbance species such as Kentucky bluegrass or creeping bentgrass (redtop) may respond with substantial regrowth following summer grazing (W. Clary, unpublished data). However, higher elevation sites, particularly those that support substantial amounts of sedges and rushes (Juncus spp.), may have less than $5 \%$ regrowth in total standing crop during August and September (Sheeter and Svejcar 1997), or only 2.5 to $5 \mathrm{~cm}$ in average additional height (W. Clary, unpublished data). Gillen et al. (1985) recorded no regrowth after July in the Blue Mountains of Oregon. Therefore, it is concluded that for some areas meaningful increases in stubble height following grazing can not be assumed, particularly at higher elevations.

\section{Indirect effects}

\section{Streambank trampling}

Grazing animals affect rangelands in many ways in addition to defoliating plants (Laycock and Harniss 1974, Skinner 1998). The general effects of soil compaction by large herbivores have been 
known for years (Alderfer and Robinson 1949, Lull 1959). Observers experienced in stream and riparian ecology have long noted problems of physical breakdown of streambanks when substantial livestock use occurred (Platts 1991). Heavy use by cattle can destabilize and break down streambanks as vegetation is weakened and the physical forces of hoof impacts shear off bank segments (Marlow and Pogacnik 1985, Trimble and Mendel 1995), although little specific information is available on the rates of livestock occupancy that result in measurable damage. Buckhouse et al. (1981) reported no increase in streambank erosion with moderate levels of livestock grazing, and Marlow and Pogacnik (1985) found that limiting livestock grazing to periods when streambanks were relatively dry could greatly reduce physical damage. In Idaho maintaining stubble heights of 10 to $14 \mathrm{~cm}$ allowed streambank recovery, although at a slower rate than occurred under no grazing (Clary 1999). Simulated grazing procedures have illustrated that relatively continuous hoof action can severely break down streambanks, while more restricted use can result in minimal changes (Clary and Kinney 2000).

We are not aware of studies that document the relationship between texture of substrate material and effectiveness of stubble height as a riparian management tool. Experiences of various people suggest that use of stubble height as a primary management guide is limited if streambank composition is fine textured and moist during the grazing period, and if it is particularly vulnerable to hoof shear. In those cases, streambank disturbance may have to be monitored directly or grazing may have to be limited to periods when the streambanks are dry (Chaney et al. 1993, D. Dallas, C. Marlow, and S. Smith, personal communications).

The relative preference for plant communities will change during the grazing period because of changing levels of forage availability and quality among sites and community types (Korpela 1992). Although cattle are generally more attracted to moist riparian areas than to drier uplands, grazing in the early part of the growing season often results in livestock concentrating their use on the drier, and often more grass-dominated, portions of the meadow or surrounding landscape (Marlow and Pogacnik 1986, Kovalchik 1987, Korpela 1992, Clary and Booth 1993, Hall and Bryant 1995, Huber et al. 1995, Krueger 1996). Other things being equal for a grazed site, the taller stands will be selected first because bite mass and instantaneous intake rates are higher in taller stands (Laca et al. 1994, Demment et al. 1995, Distel et al. 1995). Cattle intake and preferences can be affected when forage stubble heights are reduced to about 7-10 cm (Ungar et al. 1991, Hall and Bryant 1995). At that point, cattle often shift their grazing use to plant communities initially considered less desirable to maintain needed intake levels (Korpela 1992, Bailey et al. 1996). As forage supplies are consumed in the uplands and dry meadows, livestock will move to locations where supplies are greater (Stuth 1991). In some instances, palatability and digestibility or comfort concerns may temporarily override forage height and abundance issues (Hodgson and Wilkinson 1968, Kinney and Clary 1998), but eventually the animals will move to feeding stations where they can maintain needed intake rates (Bailey et al. 1996). Cattle will increase their use of hydrophilic vegetation near the stream edge as stubble heights on the adjacent dry meadows become short and intake is reduced. However, there will be less impetus for the animals to shift to wet streamside areas if adequate feed intake can be maintained on drier locations.

Phenology is an important factor in distribution of grazing between riparian and upland areas. When forage matures and digestibility decreases, forage intake declines even though adequate forage is available (Redmon et al. 1995). Differential plant drying and maturation between riparian and adjacent areas can result in cattle shifting feeding stations to riparian areas, although there still could be adequate forage available on adjacent drier areas (Hall and Bryant 1995). Thus, appropriate upland stubble heights, as a guide to management, can potentially vary throughout the season because as upland forages mature greater stubble heights and stand biomass may be necessary to retain livestock grazing activity.

Livestock movement rates increase as the animals attempt to maintain forage intake as stand heights decrease and, therefore, bite weight and the intake rate decrease (Johnstone-Wallace and Kennedy 1944, Wright et al. 1990, Demment et al. 1995, Bailey et al. 1996). This increased movement and trailing can result in substantially more compaction and trampling damage to streambanks (USDA-FS and USDI-BLM 1993). Skinner (1998) suggested that plant stubble heights of both wet streamside areas and adjacent dry meadow or terrace areas could be used to gage when livestock activity along streambanks may increase to a point where bank breakdown might occur more frequently. No specific guidelines were suggested.

\section{Browsing of riparian shrubs}

Ungulate grazing strategies for riparian areas can be successful if they integrate animal behavior, forage palatability, plant physiology, plant community responses, hydrology, and physical site characteristics (Krueger 1996). As part of this complex consideration, experienced observers have suggested that substantial grazing of willows (Salix spp.) and other important riparian shrubs usually does not occur if a sufficient herbaceous forage supply is present, particularly if the forage is lush and palatable (Roath and Krueger 1982a, Kauffman et al. 1983, Mosley et al. 1997). Conversely, when herbaceous forage is in short supply or has matured, increases in willow consumption by cattle are expected (Hall and Bryant 1995, Skinner 1998). Hall and Bryant (1995) estimated that little use of riparian shrubs will occur if at least $7.6 \mathrm{~cm}$ of herbaceous stubble height remains. Observations by Kovalchik and Elmore (1992) suggest that mid to late season shrub use would begin at about 10 to $15 \mathrm{~cm}$ of forage stubble height, and browsing would continue to increase until cattle would browse all the willows they could reach when herbaceous stubble heights were reduced to less than $5 \mathrm{~cm}$ in height. It is unclear, however, how stubble height interacts with forage preference when the forage species are highly preferred, but of low stature. Anecdotal accounts vary on this issue.

A study specifically directed toward answering the question of the effect of residual forage on grazing use of willows was conducted in Colorado. The effects of season of use and that of residual forage stubble height on the proportion of willows in steer diets were separated through the use of a series of grazing paddocks. Results showed that some willow was consumed throughout the grazing season, but large increases in consumption occurred during the fall grazing period and anytime herbaceous stubble heights were short (Pelster 1998). Generally, willow consumption increased as forage stubble heights decreased to $15 \mathrm{~cm}$ in spring and early summer, while about $20 \mathrm{~cm}$ of stubble was needed to reduce willow consumption in late summer and fall. These findings, from a productive site $\left(\sim 3200 \mathrm{~kg} \mathrm{ha}^{-1}\right.$ of herbage $)$ dominated by water sedge (Carex aquatilis Wahl.) and beaked sedge, indicated a greater stubble height (i.e., more conserva- 
tive management) might be required to adequately protect the willow community than was previously realized, at least in willow/tall sedge communities (Fig. 1).

\section{Livestock gains}

High daily gain is the keystone of effective livestock production. Maintenance of high rates of forage intake is necessary to accomplish this objective. Various factors affect rates of intake. The intake rate of foraging livestock is greatest in areas of abundant, palatable forage (Stuth 1991, Bailey et al. 1996). When the quantity of forage available is adequate, intake may be regulated by forage digestibility (Hodgson and Wilkinson 1968, Huston and Pinchak 1991, Redmon et al. 1995). Otherwise, the total mass of forage available directly affects intake rates (Johnstone-Wallace and Kennedy 1944, Handl and Rittenhouse 1972, Hobbs et al. 1996). Numerous studies have shown that bite depth, bite volume, intake rate, and total intake are related to the height of the forage stand (i.e., stubble height) (Allden and Whittaker 1970, Chacon and Stobbs 1976, Burlison et al. 1991, Laca et al. 1992, Laca et al. 1994). When the forage supply is largely consumed, bite size decreases and there is a markedly lower intake of herbage as compared to when stand heights are greater.

Stubble heights of $10 \mathrm{~cm}$ or less are often related to significant depressions in forage intake by cattle (Ungar et al. 1991). Cattle are bulk roughage grazers that use a tongue sweep to aid in forage ingestion (Huston and Pinchak 1991). The effectiveness of the tongue sweep is greatly reduced when forage heights are short, which contributes to reduction in bite volume (Ungar et al. 1991, Hall and Bryant 1995). Cattle may be reluctant to graze forage stands of only $4 \mathrm{~cm}$ in height (Ungar et al. 1991). For example, if 50\% of the biomass of tufted hairgrass (Deschampsia cespitosa (L.) Beauv.) is removed, only about $4 \mathrm{~cm}$ of stubble height will remain (Kinney and Clary 1994), well below the optimum foraging lengths. Thus, even though tufted hairgrass is a preferred forage species (Clary and Booth 1993), a switch to other taller community-types may occur quickly if animals are to maintain dietary intake.

\section{Measurement and communication}

Sampling of stubble height can be relatively simple compared with many other vegetation measurements, or somewhat difficult depending on stand characteristics. Upland bunchgrass stands often are grazed

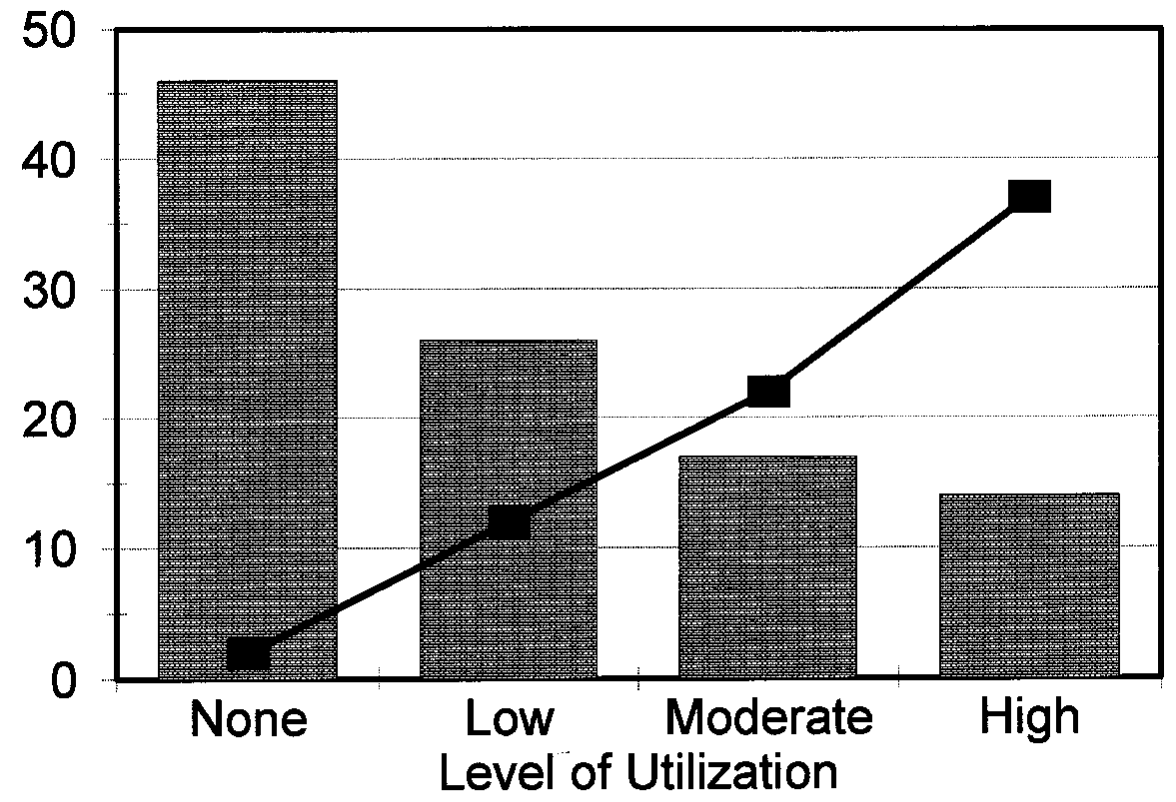

\section{Stubble ht $(\mathrm{cm})+$ Diet $(\%)$}

Fig. 1. Proportion of willow biomass in steer diets at different residual forage stubble heights. Data presented are average values for all stubble height levels from spring through fall, Sheep Creek, Colo. (after Pelster 1998).

irregularly, which makes interpretation of stubble height a problem (McKinney 1997). Alternatively, in more uniform or sod-like stands, grazing animals tend to remove the forage by horizons or levels (Laca et al. 1994). Sod-like stands of comparatively consistent plant composition often occur in riparian meadows within uniform soil moisture strata. This characteristic allows stubble height to be a more easily sampled variable on riparian areas than on many other rangelands.

Average riparian stubble height is typically determined by transects along the streamside area (K. Crane, personal communication). However, stubble height distributions in riparian areas, even though more uniform than on many upland sites, are often skewed with a portion of tall heights causing the average stubble height to be greater than other measures of central tendency (Gibb and Ridout 1988, D. Blackstun personal communication). The Bureau of Land Management has prepared a photographic guide to aid managers in rapidly judging median stubble heights (USDI-BLM 1999). Another rapid sampling approach for stubble height uses sequential sampling of plots recorded as meeting or not meeting a stubble height standard. This method has the advantages of avoiding the skewness issue, being rapid, and providing statistically defend- able answers (Turner and Clary 2001).

The comparative ease of sampling stubble height aids in the manager-user communication process. Easily understood and communicated management goals are necessary, particularly when public lands are involved. While vegetation successional stage and trend are generally the appropriate long-term management goals, shortterm objectives or guidelines are also necessary to help attain the long-term goals (Leonard et al. 1997). Forage utilization has been long used as a short-term objective, but determining what is missing, as a result of grazing, often is difficult. Herbaceous stubble height is easier to document and communicate than is utilization; that is, it is easier to measure what is still there than to estimate what has been removed and explain it to a varied audience (Leonard et al. 1997, Sanders 1998, Skinner 1998). Residual stubble height serves as an approximate visual guide for a variety of potential grazing impacts and therefore, can be used by the manager to make decisions on livestock use and movement (Hall and Bryant 1995, Skinner 1998).

\section{Overall riparian system response to control of stubble height}

Well documented evaluations of riparian area responses to control of streamside 
stubble height are limited. One evaluation of a grazing allotment in Montana compared streambank alteration, stubble height, and woody plant and forage utilization as predictors of stream channel cross-section modification. All variables examined had relatively low correlations with stream channel changes, although stubble height and percentage change in stubble height appeared to be the most useful measures (Rhodes et al. 1996).

A study that evaluated use of stubble height criteria was conducted in a central Idaho mountain meadow that had historically experienced heavy cattle grazing during the growing season. Three treatments were applied in the last half of June: no grazing; light grazing (20-25\% utilization); and moderate grazing (35-50\% utilization) during the 10 year study. Stream width and depth, streambank stability, channel bottom embeddedness, willow cover and height, plant species richness by growth form, plant community-type, and plant and litter cover were among the variables measured. Virtually all streamside variables changed from initial conditions toward conditions more beneficial for salmonid fisheries habitat when pastures were not grazed or when pastures were grazed to a $14 \mathrm{~cm}$ streamside stubble height. A lesser number of variables improved when pastures were grazed to a $10 \mathrm{~cm}$ streamside graminoid stubble height (Clary 1999). Although this study did not include a stubble height treatment (and associated grazing intensity) that would be too severe for any riparian recovery, we consider that it has provided evidence for defining a critical forage stubble height for the mountain meadow situation studied. Notwithstanding that most measured variables under the $10 \mathrm{~cm}$ stubble height treatment responded positively during the 10 year study, several important variables did not recover or recovered very slowly from initial conditions (Clary 1999 and unpublished data). Such a reaction did not occur under the 14 $\mathrm{cm}$ stubble height treatment. This suggests that the $10 \mathrm{~cm}$ stubble height treatment in this ecosystem approached a degree of grazing stress that could have resulted in a failure of the riparian area to recover.

\section{Research Needs}

All is not known about the application of stubble height criteria to the management of riparian grazing. In fact, relatively little direct investigation has been conducted. Additional research is needed to increase the scientific basis for the use of stubble height as a tool to manage riparian areas. Work is particularly needed in the following areas:

*The determination of where a stubble height guideline is efficient and effective, and where it is not appropriate. For example, the authors' experience suggest that, for smaller mountain meadow streams that widen under grazing stress, use of stubble height to guide management appears to be very effective. Best Management Practice guidelines developed under the Idaho Agricultural Pollution Abatement Plan (IDEQ-ISCC 1993) suggest that stubble height criteria should be used where streambank stability is dependent upon herbaceous plants. Alternatively, woody plant utilization or streambank disturbance should be used as a management guide in situations where streambank stability is controlled by substrate or the stream is deeply incised.

*Determination of proper stubble heights in high elevation or other sites where species composition and growing conditions result in relatively low statured forage plants. Even though grazing to a short stubble height in these situations can be acceptable from a plant physiology standpoint, other issues as forage intake, animal movement, and woody plant browsing would still be potential concerns.

*Evaluation of the relative preference of herbaceous vegetation and willows in dif ferent seasons under different combina tions of herbaceous and woody species, and at different forage stubble heights. The only quantitative study to date has been in a high elevation, tall sedge community in Colorado.

*Documentation of the direct impacts of livestock on streambanks of different stream types, parent materials, moisture conditions, and livestock occupancy levels as guided by stubble height.

*Increased understanding of channel evolution and how recovery processes affect the local flood plain watertable and the greenline (Winward 2000) vegetation in relation to different grazing intensities and residual stubble heights.

\section{Conclusions and Management Implications}

The use of stubble height as a grazing management guide is not new and its use has been questioned in some situations. However, as we understand more about the complexities and interactions within riparian areas we realize why this variable has meaningful application there.
Although the direct benefits of maintaining minimum stubble heights may be limited to such items as sustaining forage plant vigor and the stabilization of streambank-building sediments, numerous indirect benefits occur as well. Many of these benefits are related to the physical manner in which cattle graze. When stubble heights are reduced to $7-10 \mathrm{~cm}$, cattle forage intake declines because the tongue sweep becomes ineffective and foraging efforts become less efficient. If stubble heights are maintained at lengths compatible with high forage intake (generally 10 $\mathrm{cm}$ or more), substantially less browsing of willows and other riparian shrubs should occur, although about a $20 \mathrm{~cm}$ stubble height was required to lessen late summer consumption of willows in a Colorado tall sedge community. The taller the remaining forage heights, the less time cattle have spent grazing on the site. In addition, there is less chance of excessive trailing as livestock search for improved forage supplies to maintain forage intake. Using stubble height to monitor foraging behavior and physical impacts may even be more important than maintaining stubble heights that support plant vigor and sediment deposition (Skinner 1998).

Monitoring of stubble on adjacent drier meadows or uplands (using separate criteria for dry areas) is also important in riparian management. Cattle usually prefer the drier portions of mountain meadows in the spring or early summer because of the avoidance of wetter soils and the preference for the normally more grassy plant composition. As grazing reduces forage stature and the mechanics of cattle foraging change intake rates, the foraging animals will move to areas where taller forage is available; often streamside riparian areas.

One of the most obvious benefits for the use of stubble height as a management guide is the communication factor. As compared to forage utilization (which is a measure of what has been removed), stubble height is easier for people to visualize. This alone makes stubble height a worthwhile measure to use on many riparian grazing areas.

Based on numerous observations by experienced professionals (e.g., A. Winward, E. Cowley, F. Reed, and T. Ratcliff, personal communications) and limited research, we conclude that a streamside stubble height of approximately $10 \mathrm{~cm}$ (Fig. 2) may be near optimal in many, but not all, situations when considering a number of riparian issues-such as maintaining forage vigor, entrapping and stabilizing sediment under inundated flow, 


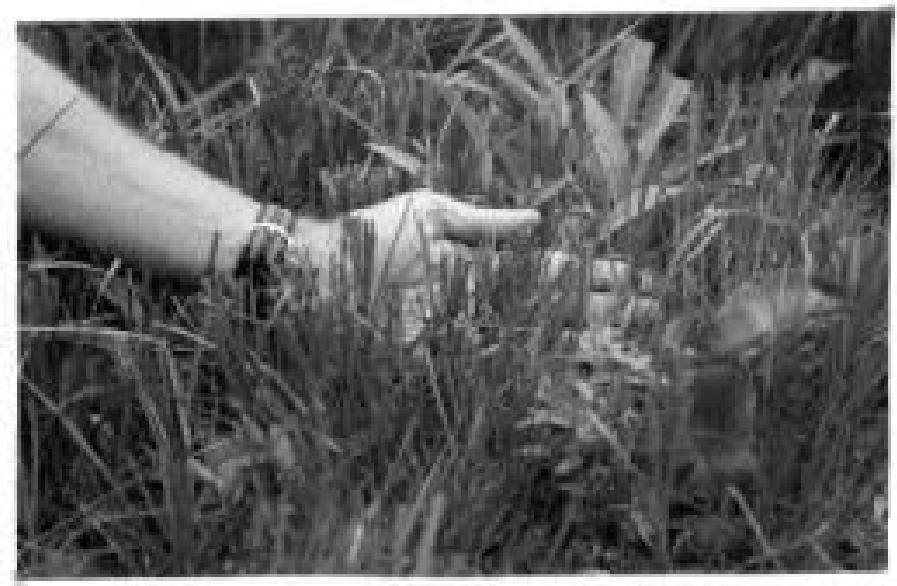

a. About right

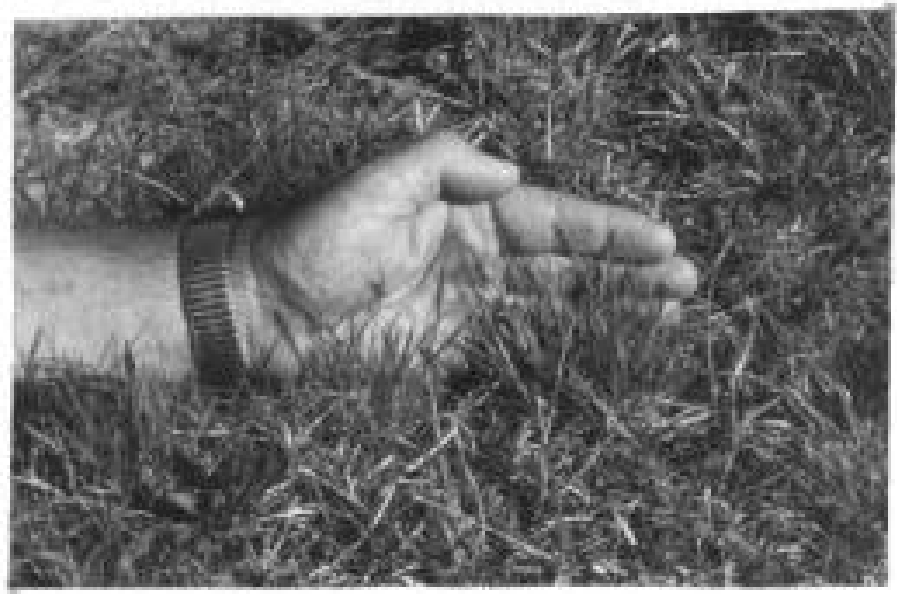

b. Too short

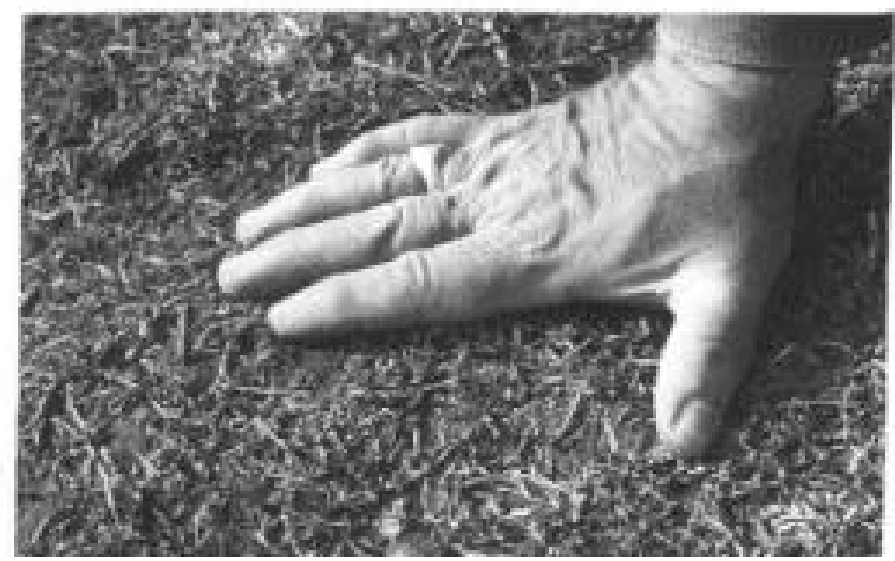

c. Gone

Fig. 2. The suggested stubble height is similar to the width of one's hand. a. About right, b. Too short, c. Gone.

trampling of streambanks, sustaining forage intake and cattle gains, and diversion of willow browsing-taken as a whole. We recognize that any given height can be satisfactory for some processes and less so for others. Therefore, no single height will likely be optimal for all riparian processes. It appears, however, that the $10 \mathrm{~cm}$ height may be the best compromise in many situations.

We anticipate that this criterion will be most meaningful when applied to sites near the stream edge, that is, areas that can be described as streamside, or near-stream areas of hydrophilic or potentially hydrophilic vegetation. Such areas are the most dynamic and sensitive because of their interaction with moving water, and because moist site woody vegetation is often present. We also anticipate that residual vegetation criteria will be most effective in protecting "small stream" sys- tems, ones in the approximate range of perhaps a few centimeters to about $5 \mathrm{~m}$ in width occurring in meadow settings. Such settings are often associated with C, D, and E stream types (Rosgen 1996). This is roughly equivalent to the Best Management Practice component in Idaho wherein a minimum stubble height is required along the greenline (Winward 2000) at the end of the growing and grazing season if streambank stability is dependent upon herbaceous vegetation. If the streambank stability is controlled by substrate or the channel is incised, other grazing guidelines will be used (IDEQISCC 1993).

The suggestion of a specific streamside stubble height is for the purpose of a start ing point when initiating improved riparian management, one that can be changed as monitoring indicates. In some situations, $7 \mathrm{~cm}$ or even less stubble height may provide for adequate riparian ecosystem function, while under other conditions $15-20 \mathrm{~cm}$ of stubble height may be required to reduce willow browsing or to limit animal impact on vulnerable streambanks. Sometimes direct monitoring of browsing or streambank breakdown will be necessary to adequately protect sensitive areas (Bengeyfield and Svoboda 1998). The $10 \mathrm{~cm}$ criteron is not suggested for specific application on dry meadows or other similar sites.

\section{Epilogue}

No single management approach is best for all situations, nor perhaps is even required for a given situation (Clary and Webster 1989, Ehrhart and Hansen 1997, Larsen et al. 1998). Likewise, no management tool serves all purposes. Stubble height of riparian forages can serve as a direct and indirect (surrogate) guide for gaging current grazing impacts. However, this short-term management guide does not fill the role of a long-term management objective. That role is filled by such concepts as Potential Natural Community, Desired Future Condition, or Properly Functioning Condition (Winward 1989, Prichard et al. 1993, Kaufmann et al. 1994). A manager should have a clear picture of the desired ecological structure and function before setting a specific height standard. As ecological succession progresses, the stubble heights that yield the desired results could also change (W. Krueger and Q. Skinner, personal communications).

Short-term management guides are 
methods to help the manager attain longterm objectives, but don't represent longterm objectives. Nor do stubble height criteria represent a "management system." The grazing management system selected and applied by the manager should meet both short- and long-term objectives. Remember, a management system or guide is applied to help achieve a goal or objective; the management system or guide is not the objective.

\section{Literature Cited}

Abt, S.R., W.P. Clary, and C.I. Thornton. 1994. Sediment deposition and entrapment in vegetated streambeds. J. Irrig. Drain. Eng. 120:1098-1111.

Alderfer, R.B. and R.R. Robinson. 1949. Runoff from pastures in relation to grazing intensity and soil compaction. J. Amer. Soc. Agron. 39:948-958.

Allden, W.G. and I.A. McD. Whittaker. 1970. The determinants of herbage intake by grazing sheep: the interrelationship of factors influencing herbage intake and availability. Aust. J. Agr. Res. 21:755-766.

Armour, C., D. Duff, and W. Elmore. 1994. The effects of livestock grazing on western riparian and stream ecosystem. Fisheries 19:9-12.

Bailey, D.W., J.E. Gross, E.A. Laca, L.R. Rittenhouse, M.B. Coughenour, D.M. Swift, and P.L. Sims. 1996. Mechanisms that result in large herbivore grazing distribution patterns. J. Range Manage. 49:386-400.

Bedunah, D.J. and R.E. Sosebee (eds.). 1995. Wildland plants: physiological ecology and developmental morphology. Soc. Range Manage., Denver, Colo.

Bell, T.A. 1998. Sediment trapping by riparian vegetation of varying heights for gully restoration. M.S. Thesis, Univ. of Nevada. Reno, Nev.

Belsky, A.J., A. Matzke, and S. Uselman. 1999. Survey of livestock influences on stream and riparian ecosystems in the western United States. J. Soil and Water Cons. 54:419-431.

Bement, R.E. 1969. A stocking-rate guide for beef production on blue-grama range. J. Range Manage. 22:83-86.

Bengeyfield, P. and D. Svoboda. 1998. Determining allowable use levels for livestock movement in riparian areas, $\mathrm{p}$. 243-257. In: D.F. Potts (ed.), Proc. AWRA Speciality Conference: Rangeland management and water resources. Amer. Water Resour. Assoc. Herndon, Virg.

Beschta, R.L. and W.S. Platts. 1986. Morphological features of small streams: significance and function. Water Resourc. Bull. 22:369-379.

Bjornn, T.C. and D.W. Reiser. 1991. Habitat requirements of salmonids in streams, $\mathrm{p}$. 83-138. In: W.R. Meehan (ed.), Influences of forest and rangeland management on salmonid fishes and their habitats. Amer. Fish. Soc. Spec. Pub. 19. Bethesda, Md.
Bonham, C.D. 1989. Measurements for terrestrial vegetation. John Wiley and Sons, New York, N.Y.

Brown, D. 1954. Methods of surveying and measuring vegetation. Commonwealth Bur. of Pastures and Field Crops. Bull. 42. Commonwealth Agr. Bur., Farnham Royal, Bucks, England.

Buckhouse, J.C., J.M. Skovlin, and R.W. Knight. 1981. Streambank erosion and ungulate grazing relationships. J. Range Manage. 34:339-340.

Burlison, A.J., J. Hodgson, and A.W. Illius. 1991. Sward canopy structure and the bite dimensions and bite weight of grazing sheep. Grass and Forage Sci. 46:29-38.

Busch, D.E. and M.L. Scott. 1995. Western riparian ecosystems, p. 286-290. In: Our living resources: a report to the nation on the distribution, abundance, and health of U.S. plants, animals, and ecosystems. USDI Nat. Biol. Sur. Washington, D.C.

Canfield, R.H. 1942a. A short-cut method for estimating grazing use. USDA For. Serv. Southwest. For. and Range Exp. Sta. Res. Note 99. Tucson, Ariz.

Canfield, R.H. 1942b. Sampling ranges by the line interception method: plant cover-composition-density-degree of forage use. USDA For. Serv. Southwest. For. and Range Exp. Sta. Res. Rep. 4. Tucson, Ariz.

Canfield, R.H. 1944. Measurement of grazing use by the line interception method. J. For 42:192-194.

Chacon, E. and T.H. Stobbs. 1976. Influence of progressive defoliation of a grass sward on the eating behavior of cattle. Aust. J. Agric. Res. 27:709-727.

Chaney, E., W. Elmore, and W.S. Platts. 1993. Managing change: livestock grazing on western riparian areas. Report prepared for the Environ. Protection Agency. Northw.Resour. Infor. Center. Eagle, Ida.

Clary, W.P. 1995. Vegetation and soil responses to grazing simulation on riparian meadows. J. Range Manage. 48:18-25.

Clary, W.P. 1999. Stream channel and vegetation responses to late spring cattle grazing. J. Range Manage. 52:218-227.

Clary, W.P. and G.D. Booth. 1993. Early season utilization of mountain meadow riparian pastures. J. Range Manage. 46:493-497.

Clary, W.P. and J.W. Kinney. 2000. Streambank response to simulated grazing. p. 292-295. In: P.F. Ffolliott, M.B. Baker, Jr., C.B. Edminister, M.C. Dillon, and (K.L. Mora (tech. coords), Land Stewardship in the $21^{\text {st }}$ century: the contributions of watershed management. USDA For. Serv. Proc. RMRSP-13.

Clary, W.P., C.I. Thornton, and S.R. Abt. 1996. Riparian stubble height and recovery of degraded streambanks. Rangelands 18:137-140.

Clary, W.P. and B.F. Webster. 1989. Managing grazing of riparian areas in the Intermountain Region. USDA For. Serv. Gen. Tech. Rep. INT-263.

Cook, C.W. and J. Stubbendieck (eds.). 1986. Range research: basic problems and techniques. Soc. Range Manage., Denver, Colo.
Corley, C.J., G.W. Frasier, M.J. Trlica, F.M. Smith, and E.M. Taylor, Jr. 1999. Nitrogen and phosphorus in runoff from 2 montane riparian communities. J. Range Manage. 52:600-605.

Crafts, E.C. 1937. Proper utilization of bunchgrass range. USDA For. Serv. Southw. For. and Range Exp. Sta. Res. Note 12. Tucson, Ariz.

Demment, M.W., J.-L. Peyraud, and E.A. Laca. 1995. Herbage intake at grazing: a modeling approach, p. 121-141. In: M. Journet, E. Grenet, M.-H. Farce, M. Theriez, and C. Demarquilly (eds.), Recent developments in the nutrition of herbivores. Proc. IVth Int. symposium on the nutrition of herbivores. INRA Editions, Paris.

Distel, R.A., E.A. Laca, T.C. Griggs, and M.W. Demment. 1995. Patch selection by cattle: maximization of intake rate in horizontally heterogeneous pastures. Appl. Anim. Behaviour Sci. 45:11-21.

Dunaway, D. S.R. Swanson, J. Wendel, and W. Clary. 1994. The effect of herbaceous plant communities and soil textures on particle erosion of alluvial streambanks. Geomorphology 9:47-56.

Ehrhart, R.C. and P.L. Hansen. 1997. Effective cattle management in riparian zones: a field survey and literature review. USDI Bur. Land Manage. Mont. BLM Riparian Tech. Bull. 3. Missoula, Mont.

Fitch, L. and B.W. Adams. 1998. Can cows and fish co-exist? Can. J. Plant Sci. 78:191-198.

Frasier, G.W., M.J. Trlica, W.C. Leininger, R.A. Pearce, and A. Fernald. 1998. Runoff from simulated rainfall in 2 montane riparian communities. J. Range Manage. 51:315-322.

Frost, W.E., E.L. Smith, and P.R. Ogden. 1994. Utilization guidelines. Rangelands $16: 256-259$.

George, M. 1996. Management practices to change livestock behavior in grazed watersheds, p. 37-46. In: M.R. George (tech. coord.), Livestock management in grazed watersheds: a review of practices that protect water quality. UCD Animal Agricultural Research Center, Pub. 3381. Oakland, Calif.

Gibb, M.J. and M.S. Ridout. 1988. Application of double normal frequency distributions fitted to measurements of sward height. Grass and Forage Sci. 43:131-136.

Gillen, R.L., W.C. Krueger, and R.F. Miller. 1985. Cattle use of riparian meadows in the Blue Mountains of northeastern Oregon. J. Range Manage. 38:205-209.

Green, D.M. and J.B. Kauffman. 1989. Nutrient cycling at the land-water interface: the importance of the riparian zone, p. 61-68. In: R. E. Gresswell, B.A. Barton, and J.L. Kershner (eds.), Practical approaches to riparian resource management: an educational workshop. USDI Bur. Land Manage. Billings, Mont.

Gregory, S.V., F.J. Swanson, W.A. McKee, and K.W. Cummins. 1991. An ecosystem perspective of riparian zones. BioScience 41:540-551. 
Groeneveld, D.P. and D. Or. 1994. Water table induced shrub-herbaceous ecotone: hydrologic management implications. Water Resour. Bull. 30:911-920.

Hall, F.C. and L. Bryant. 1995. Herbaceous stubble height as a warning of impending cattle grazing damage to riparian areas. USDA For. Serv. Gen. Tech. Rep. PNW-GTR-362.

Handl, W.P. and L.R. Rittenhouse. 1972. Herbage yield and intake of grazing steers. Proc. West. Sect. Amer. Soc. Anim. Sci. 23:197-200.

Hansen, P.L., R.D. Pfister, K. Boggs, B.J. Cook, J. Joy, and D. K. Hinckley. 1995. Classification and management of Montana's riparian and wetland sites. Mont. For. and Cons. Exp. Sta. Misc. Publ. 54. Missoula, Mont.

Hawkins, C.P. 1994. What are riparian ecosystems and why are we worried about them?, p. 2-9. In: G.A. Rasmussen and J.P. Dobrowolski (eds.), Riparian resources: a symposium on the disturbances, management, economics, and conflicts associated with riparian ecosystems. Coll. of Natur. Resour., Utah St. Univ., Logan, Ut.

Heady, H.F. and R.D. Child. 1994. Rangeland ecology and management. Westview Press, Boulder, Colo.

Hill, A.R. 1996. Nitrate removal in stream riparian zones. J. Environ. Qual. 25:743-755.

Hobbs, N.T., D.L. Baker, G.D. Bear, and D.C. Bowden. 1996. Ungulate grazing in sagebrush grassland: effects of resource competition on secondary production. Ecol. Appl. 6:218-227.

Hodgson, J. and J.M. Wilkinson. 1968. The influence of the quantity of herbage offered and its digestibility on the amount eaten by grazing cattle. J. Brit. Grassl. Soc. 23:75-80.

Holechek, J.L., H. de Souza Gomes, F. Molinar, and D. Galt. 1998. Grazing intensity: critique and approach. Rangelands 20:15-18.

Holechek, J. L., H. Gomez, F. Molinar, and D. Galt. 1999. Grazing studies: what we've learned. Rangelands 21:12-16.

Holechek, J.L., R.D. Pieper, and C.H. Herbel. 1989. Range management: principles and practices. Prentice Hall, Englewood Cliffs, N.J.

Huber, S.A., M.B. Judkins, L.J. Krysl, T.J. Svejcar, B.W. Hess, and D.W. Holcombe. 1995. Cattle grazing a riparian mountain meadow: effects of low and moderate stocking density on nutrition, behavior, diet selection, and plant growth response. J. Anim. Sci. 73:3752-3765.

Hussey, M.R., Q.D. Skinner, J.C. Adams, and A.J. Harvey. 1985. Denitrification and bacterial numbers in riparian soils of a Wyoming mountain watershed. J. Range Manage. 38:492-496.

Huston, J.E. and W.E. Pinchak. 1991. Range animal nutrition, p. 27-63. In: R.K. Heitschmidt and J.W. Stuth (eds.), Grazing management: an ecological perspective. Timber Press, Portland, Ore.
Idaho Division of Environmental Quality and Idaho Soil Conservation Commission. 1993. Idaho agricultural pollution abatement plan. Ida. Soil Cons. Comm., Boise, Ida.

Jameson, D.A. 1963. Responses of individual plants to harvesting. Bot. Rev. 29:532-594.

Johnston, C.A. 1993. Material fluxes across wetland ecotones in northern landscapes. Ecol. Appl. 3:424-440.

Johnstone-Wallace, D.B. and K. Kennedy. 1944. Grazing management practices and their relationship to the behavior and grazing habits of cattle. J. Agr. Sci. 34:190-197.

Kattelmann, R. and M. Embury. 1996. Riparian areas and wetlands, p. 201-273. In: Status of the Sierra Nevada: Vol. III: Final report to Congress. Wildl. Resour. Center Rep. 38. Univ. California, Davis, Calif.

Kauffman, J.B. and W.C. Krueger. 1984. Livestock impacts on riparian ecosystems and streamside management implications .... a review. J. Range Manage. 37:430-438.

Kauffman, J.B., W.C. Krueger, and M. Vavra. 1983. Effects of late season cattle grazing on riparian plant communities. J. Range Manage. 36:685-691.

Kauffman, J.B., W.C. Krueger, and M. Vavra. 1985. Ecology and plant communities of the riparian area associated with Catherine Creek in northeastern Oregon. Oregon Agr. Exp. Sta. Tech. Bull. 147. Corvallis, Oreg.

Kaufmann, M.R., R.T. Graham, D.A. Boyce, Jr., W.H. Moir, L. Perry, R.T. Reynolds, R.L. Bassett, P. Mehlhop, C.B. Edminster, W.M. Block, and P.S. Corn. 1994. An ecological basis for ecosystem management. USDA For. Serv. Gen. Tech. Rep. RM-246.

Kinney, J.W. and W.P. Clary. 1994. A photographic utilization guide for key riparian graminoids USDA For. Serv. Gen. Tech. Rep. INT-GTR-308.

Kinney, J.W. and W.P. Clary. 1998. Time-lapse photography to monitor riparian meadow use. USDA For. Ser. Res. Note RMRS-RN-5.

Kleinfelder, D., S. Swanson, G. Norris, and W. Clary. 1992. Unconfined compressive strength of some streambank soils with herbaceous roots. Soil Sci. Soc. Amer. J. 56:1920-1925.

Korpela, E.J. 1992. Modeling riparian zone processes: biomass production and grazing. $\mathrm{Ph}$. D. Thesis. Oregon St. Univ., Corvallis, Ore.

Kovalchik, B.L. 1987. Riparian zone associations: Deschutes, Ochoco, Fremont, and Winema National Forests. USDA For. Serv. Region 6. Ecol. Tech. Pap. 279-87. Portland, Ore

Kovalchik, B.L. and W. Elmore. 1992. Effects of cattle grazing systems on willowdominated plant associations in central Oregon, p. 111-119. In: W.P. Clary, E.D. McArthur, D. Bedunah, and C.L. Wambolt (comps.), Proc. symposium on ecology and management of riparian shrub communities. USDA For. Serv. Gen. Tech. Rep. INT-289. Ogden, Ut.
Krueger, W.C. 1996. Managing ungulates to allow recovery of riparian vegetation, p.160-164. In: Proc. symposium on sustaining rangeland ecosystems. Oregon St. Univ. Ext. Serv. Corvallis, Ore.

Laca, E.A., R.A. Distel, T.C. Griggs, and M.W. Demment. 1994. Effects of canopy structure on patch depression by grazers. Ecol. 75:706-716

Laca, E.A., E.D. Ungar, N. Seligman, and M.W. Demment. 1992. Effects of sward height and bulk density on bite dimensions of cattle grazing homogeneous swards. Grass and Forage Sci. 47:91-102.

Lamman, J.S. 1994. Effects of season and intensity of defoliation on two important montane riparian species. M.S. Thesis. Colorado St. Univ., Fort Collins, Colo.

Larsen, R.E., W.C. Krueger, M.R. George, M.R. Barrington, J.C. Buckhouse, and D.E. Johnson. 1998. Viewpoint: livestock influences on riparian zones and fish habitat: literature classification. J. Range Manage. 51:661-664.

Larson, G.E. 1993. Aquatic and wetland vascular plants of the northern Great Plains. USDA For. Serv. Gen. Tech. Rep. RM-238.

Laycock, W.A. and R.O. Harniss. 1974. Trampling damage on native forb-grass ranges grazed by sheep and cattle, p. 349-354. In: Grassland utilization. Sec., XII. Int. Grassl. Congr., Moscow, Russia.

Leonard, S., G. Kinch, V. Elsbernd, M. Borman, and S. Swanson. 1997. Riparian area management. USDI Bur. Land Manage. Tech. Ref. 1737-14. Denver, Colo.

Logan, R.S. 1997. Riparian forest wildlife: guidelines for landowners and loggers. Montana St. Univ. Ext. Pub. EB 146. Bozeman, Mont.

Lull, H.W. 1959. Soil compaction on forest and range lands. USDA For. Serv. Misc. Publ. 768. Washington, D.C.

Manning, M.E., S.R. Swanson, T. Svejcar, and J. Trent. 1989. Rooting characteristics of four intermountain meadow community types. J. Range Manage. 42:309-312.

Marlow, C.B. and T.M. Pogacnik. 1985. Time of grazing and cattle-induced damage to streambanks, p. 279-284. In: R.R. Johnson, C.D. Ziebell, D.R. Patton, P.F. Ffolliott, and R.H. Hamre (tech. coords.), Riparian ecosystems and their management: reconciling conflicting uses: first North American riparian conference. USDA For. Serv. Gen. Tech. Rep. RM-120. Fort Collins, Colo.

Marlow, C.B. and T.M. Pogacnik. 1986. Cattle feeding and resting patterns in a foothills riparian zone. J. Range Manage. 39:212-217.

Masterman, R. and C.R. Thorne. 1992. Predicting influence of bank vegetation on channel capacity. J. Hydraulic Eng. 118:1052-1058.

McKinney, E. 1997. It may be utilization, but is it management? Rangelands 19:4-7.

Meehan, W.R., F.J Swanson, and J.R. Sedell. 1977. Influences of riparian vegetation on aquatic ecosystems with particular reference to salmonid fishes and their food supply, $\mathrm{p}$. 
137-145. In: R.R. Johnson and D.A. Jones (tech. coords.), Importance, preservation and management of riparian habitat: a symposium. USDA For. Serv. Gen. Tech. Rep. RM-43.

Mitchell, J.E., R. Elderkin, and J.K. Lewis. 1993. Seasonal height-weight dynamics of western wheatgrass. J. Range Manage. 46:147-151.

Morisawa, M. 1968. Streams: their dynamics and morphology. McGraw-Hill, New York, N.Y.

Mosley, J.C., P.S. Cook, A.J. Griffis, and J. O'Laughlin. 1997. Guidelines for managing cattle grazing in riparian areas to protect water quality: review of research and best management practices policy. Idaho For., Wildl. and Range Policy Analysis Group Rep.15. Idaho For., Wildl. and Range Exp. Sta., Moscow, Ida.

Murphy, M.L. and W.R. Meehan. 1991. Stream ecosystems, p. 17-46. In: W.R. Meehan (ed.), Influences of forest and rangeland management on salmonid fishes and their habitats. Amer. Fish. Soc. Spec. Pub. 19. Bethesda, Md.

Myers, L.H. 1989. Grazing and riparian management in southwestern Montana, p. 117-120. In: R. E. Gresswell, B.A. Barton, and J.L. Kershner (eds.), Practical approaches to riparian resource management: an educational workshop. USDI Bur. Land Manage. Billings, Mont.

Naiman, R.J., H. DeCamps, and M. Pollock. 1993. The role of riparian corridors in maintaining regional biodiversity. Ecol. Appl. 3:209-212.

Odum, E.P. 1978. Opening address: ecological importance of the riparian zone, p. 2-4. In: Strategies for protection and management of flood plain wetlands and other riparian ecosystems: proceedings of the symposium. USDA For. Serv. Gen. Tech. Rep. WO-12.

Oregon State University-Agricultural Experiment Station. 1998. Stubble height and utilization measurements: uses and misuses. Oregon Agr. Exp. Sta. Bull. 682. Corvallis, Ore.

Parker, K.W. 1942. General guide to satisfactory utilization of the principal southwestern range grasses. USDA For. Serv. Southw. For. and Range Exp. Sta. Res. Note 104. Tucson, Ariz.

Pearce, R.A., G.W. Frasier, M.J. Trlica, W.C. Leininger, J.D. Stednick, and J.L. Smith. 1998a. Sediment filtration in a montane riparian zone under simulated rainfall. J. Range Manage. 51:309-314.

Pearce, R.A., M.J. Trlica, W.C. Leininger, D.E. Mergen, and G. Frasier. 1998b. Sediment movement through riparian vegetation under simulated rainfall and overland flow. J. Range Manage. 51:301-308.

Pearce, R.A., M.J. Trlica, W.C. Leininger, J.L. Smith, and G.W. Frasier. 1997. Efficiency of grass buffer strips and vegetation height on sediment filtration in laboratory rainfall simulations. J. Environ. Qual. 26:139-144.
Pelster, A. 1998. Steer diets and livestock management in a montane riparian zone. M.S. Thesis, Colorado St. Univ., Fort Collins, Colo.

Pieper, R.D. 1994. Ecological implications of livestock grazing, p. 177-211. In: M. Vavra, W.A. Laycock, and R.D. Pieper (eds.), Ecological implications of livestock herbivory in the West. Soc. Range Manage., Denver, Colo.

Pinchak, W.E., M.A. Smith, R.H. Hart, and J.W. Waggoner, Jr. 1991. Beef cattle distribution patterns on foothill range. J. Range Manage. 44:267-275.

Platts, W.S. 1991. Livestock grazing, p. 389-423. In: W.R. Meehan (ed.), Influences of forest and rangeland management on salmonid fishes and their habitats. Amer. Fish. Soc. Spec. Publ. 19. Bethesda, Md.

Platts, W.S. and R.L. Nelson. 1989. Characteristics of riparian plant communities and streambanks with respect to grazing in northeastern Utah, p. 73-81. In: R.E. Gresswell, B.A. Barton, and J.L. Kershner (eds.), Practical approaches to riparian resource management: an educational workshop. USDI Bur. Land Manage. Billings, Mont.

Prichard, D., H. Barrett, J. Cagney, R. Clark, J. Fogg, K. Gebhardt, P.L. Hansen, B. Mitchell, and D. Tippy. 1993. Riparian area management: process for assessing proper functioning condition. USDI Bur. Land Manage. Tech. Ref 1737-9. Denver, Colo.

Ratliff, R.D., M.R. George, and N.K. McDougald. 1987. Managing livestock grazing on meadows of California's Sierra Nevada: a manager-user guide. Univ. Calif. Coop. Ext. Div. Agr. and Natur. Resour. Leaf. 21421. Berkeley, Calif.

Redmon, L.A., F.T. McCollum III, G.W. Horn, M.D. Cravey, S.A. Gunter, P.A. Beck, J.M. Mieres, and R.S. Julian. 1995. Forage intake by beef steers grazing winter wheat with varied herbage allowances. J. Range Manage. 48:198-201.

Ree, W.O. and V.J. Palmer. 1949. Flow of water in channels protected by vegetative linings. USDA Soil Cons. Serv. Tech. Bull 967. Washington, D.C.

Reid, E.H. and G.D. Pickford. 1941. A comparison of the ocular-estimate-by-plot and the stubble-height methods of determining percentage utilization of range grasses. J. For. 39:935-941.

Reid, E.H., and G.D. Pickford. 1946. Judging mountain meadow range condition in eastern Oregon and eastern Washington. USDA Circ. 748. Washington, D.C.

Rhodes, B.J., C.B. Marlow, and B.F. Sowell. 1996. An evaluation of riparian grazing guidelines on the Long Creek Allotment, Beaverhead National Forest, p. 64. In: Abstracts: 49th Ann. Meet. Soc. Range Manage. Wichita, Kan.

Risser, P.G. 1995. The status of the science examining ecotones. BioSci. 45:318-325.

Roath, L.R. and W.C. Krueger. 1982a. Cattle grazing influence on a mountain riparian zone. J. Range Manage. 35:100-103.
Roath, L.R. and W.C. Krueger. 1982b. Cattle grazing and behavior on a forested range. J. Range Manage. 35:332-338.

Rosgen, D. 1996. Applied river morphology. Printed Media Companies. Minneapolis, Minn.

Rumsey, C.J. 1996. The effect of three residual vegetation heights on streambank sediment deposition and vegetative production. M.S. Thesis, Univ. Wyoming, Laramie, Wyo.

Sanders, K.D. 1998. Utilization standards: the quandary revisited, p. 3-8. In: Stubble height and utilization measurements: uses and misuses. Oregon Agr. Exp. Sta. Bull. 682. Corvallis, Ore.

Schlesinger, W.H. 1991. Biogeochemistry: an analysis of global change. Academic Press. San Diego, Calif.

Schnabel, R.R., L.F. Cornish, W.L. Stout, and J.A. Shaffer. 1996. Denitrification in a grassed and a wooded, valley and ridge, riparian ecotone. J. Environ. Qual. 25:1230-1235.

Sharp, L., K. Sanders, and N. Rimbey. 1994. Management decisions based on utilizationis it really management? Rangelands 16:38-40.

Sheeter, G. and T. Svejcar. 1997. Streamside vegetation regrowth after clipping. Rangelands 19:30-31.

Skinner, Q.D. 1998. Stubble height and function of riparian communities, p. 29-46. In: Stubble height and utilization measurements: uses and misuses. Oregon Agr. Exp. Sta. Bull. 682. Corvallis, Ore.

Stoddart, L.A., A.D. Smith, and T.W. Box. 1975. Range management. McGraw-Hill, New York, N.Y.

Stuber, R.J. 1985. Trout habitat, abundance, and fishing opportunities in fenced vs. unfenced riparian habitat along Sheep Creek, Colorado, p. 310-314. In: R.R. Johnson, C.D. Ziebell, D.R. Patton, P.F. Ffolliott, and R.H. Hamre (tech. coords.), Riparian ecosystems and their management: reconciling conflicting uses: first North American riparian conference. USDA For. Serv. Gen. Tech. Rep. RM-120.

Stuth, J.W. 1991. Foraging behavior, p. 65-83. In: R.K. Heitschmidt and J.W. Stuth (eds.), Grazing management: an ecological perspective. Timber Press, Portland, Ore.

Swanson, F. 1994. Natural disturbance effects on riparian areas, p. 11-14. In: G.A. Rasmussen and J.P. Dobrowolski (eds.), Riparian resources: a symposium on the disturbances, management, economics, and conflicts associated with riparian ecosystems. Coll. of Natur. Resour., Utah St. Univ., Logan, Ut.

Temple, D.M. 1982. Flow retardance of submerged grass channel linings. Trans. ASAE 1982:1300-1303.

Thomas, J.W., C. Maser, and J.E. Rodiek. 1979. Riparian zones, p. 40-47. In: J.W. Thomas (tech. ed.), Wildlife habitats in managed forests: the Blue Mountains of Oregon and Washington. USDA For. Serv. Agric. Handb. 553. Washington, D.C. 
Thornton, C.I., S.R. Abt, and W.P. Clary. 1995. Sediment entrapment potential of submerged stream channel vegetation, p. 409-420. In: Carrying the torch for erosion control: an olympic task: proceedings of conference XXVI. Intern. Erosion Control Assoc. Steamboat Springs, Colo.

Thornton, C.I., S.R. Abt, and W.P. Clary. 1997. Vegetation influence on small stream siltation. J. Amer. Water Resour. Assoc. 33:1279-1288.

Trimble, S.W. and A.C. Mendel. 1995. The cow as a geomorphic agent-a critical review. Geomorphology 13:233-253.

Turner, D.L. and W.P. Clary. 2001. Sequential sampling for meadow pasture stubble height. J. Range Manage. 53: (in press).

Ungar, E.D., A. Genizi, and M.W. Demment. 1991. Bite dimensions and herbage intake by cattle grazing short hand-constructed swards. Agron J. 83:973-978.

USDA Forest Service. 1988. Range plant handbook. Republication of the original 1937 For. Serv. work. Dover Publications, New York, N.Y.
USDA Forest Service and USDI Bureau of Land Management. 1993. Guidelines for managing livestock in riparian areas. Coordinated Riparian Policy Statement. Butte, Mont.

USDI Bureau of Land Management. 1996. Utilization studies and residual measurements. Interagency Techn. Refer.. BLM/ RS/ST-96/004+1730. Denver, Colo.

USDI Bureau of Land Management. 1999. Photographic guide to median stubble heights. Idaho Bur. Land Manage. Tech. Bull. 99-01. Salmon, Ida.

US General Accounting Office. 1988. Public rangelands: some riparian area restored but widespread improvement will be slow. GAO/RCED-88-105. Gaithersburg, Md.

Wheeler, M.A. 1998. Seasonal grazing effects on soil physical properties in a montane riparian zone. M.S. Thesis, Colorado St. Univ., Fort Collins, Colo.

Winward, A.H. 1989. Calculating ecological status and resource value ratings in riparian areas, p. 10-11. In: W.P. Clary and B.F. Webster. Managing grazing of riparian areas in the Intermountain Region. USDA For. Serv. Gen. Tech. Rep. INT-263.
Winward, A.H. 1994. Management of livestock in riparian areas, p. 49-52. In: G.A Rasmussen and J.P. Dobrowolski (eds.), Riparian resources: a symposium on the disturbances, management, economics, and conflicts associated with riparian ecosystems. Coll. of Natur. Resour., Utah St. Univ. Logan, Ut.

Winward, A.H. 2000. Monitoring the vegetation resources in riparian areas. USDA For. Serv. Gen. Tech. Rep. RMRS-GTR-47.

Wright, I.A., T.K. Whyte, and K. Osoro. 1990. The herbage intake and performance of autumn-calving beef cows and their calves when grazing continuously at two sward heights. Anim. Prod. 51:85-92.

Zimmerman, R.C., J.C. Goodlett, and G.H. Comer. 1967. Influence of vegetation on channel form of small streams, p. 255-275. In: Intern. Assoc. Scientific Hydrology. Publ. 75. Wallingford, England.

\section{Erratum}

In the September issue of the Journal of Range Management the following information was mistakely left off the author information. The article which began on page 479 through 482 was entitled Effects of roundups on behavior and reproduction of feral hors es by Kyle V. Hansen and Jeffrey C. Mosley

The authors are former graduate research assistant, Department of Rangeland Ecology and Management, University of Idaho, Moscow, Ida. 83844; and professor, Department of Animal and Range Sciences, Montana State University, Bozeman, Mont. 59717. 